\title{
FINANSOWANIE OKRESU PRZEJŚCIOWEGO W SYSTEMIE EMERYTALNYM
}

\begin{abstract}
Streszczenie
Celem badawczym pracy była analiza wpływu postanowień decydentów na rachunki Zakładu Ubezpieczeń Społecznych w latach 1999-2012. Aby osiągnąc cel, autor postanowił zweryfikować następujące hipotezy badawcze:

- $\quad$ Zakład Ubezpieczeń Społecznych uzyskał nadwyżkę między wpływami ze składek a wydatkami do pokrycia ze składek do roku 2012;

- $\quad$ źródłem refundacji kwot składek z Zakładu Ubezpieczeń Społecznych do Otwartych Funduszy Emerytalnych są wpływy z prywatyzacji;

- $\quad$ reformie systemu emerytalnego towarzyszą działania zmierzające do ukrócenia przywilejów sektorowych oraz grup społecznych, służących zmniejszeniu wydatków państwa.

W wyniku przeprowadzonych badań, zweryfikowano negatywnie zakładane hipotezy badawcze:

- Zakład Ubezpieczeń Społecznych nie uzyskał nadwyżki między wpływami ze składek a wydatkami do pokrycia ze składek do roku 2012 - coroczny deficyt, w tym w 2012 roku w wysokości 54,8 mld PLN, tj. 31,1\%;

- $\quad$ wpływy z prywatyzacji okazały się zbyt niskie - w latach 1999-2012 zrefundowały przekazanie składek do Otwartych Funduszy Emerytalnych jedynie w 47\%;

- $\quad$ reformie systemu emerytalnego przez długi okres nie towarzyszyły działania zmierzające do ukrócenia przywilejów sektorowych oraz grup społecznych, służących zmniejszeniu wydatków państwa, co więcej, przywileje powiększano - wyłączenie z powszechnego systemu emerytur mundurowych, przedłużenie możliwości nabywania prawa do wcześniejszej emerytury, wprowadzenie emerytur górniczych, redukcja składki rentowej.
\end{abstract}

Słowa kluczowe: Zakład Ubezpieczeń Społecznych (ZUS), Otwarte Fundusze Emerytalne (OFE), system emerytalny

\section{FINANCING TRANSITION PERIOD IN POLISH PENSION SYSTEM}

\section{Summary}

The purpose of the research study is to analyse the impact of the provisions established by policymakers on the accounts of the Polish Social Insurance Institution in the years 1999-2012. The author has set out to verify the following hypotheses:

- Social Security Institution received a surplus of revenue from contributions over expenditures to be covered by contributions until year 2012;

1 dr Mariusz Dybał - Wydział Prawa i Administracji i Ekonomii, Uniwersytet Wrocławski; e-mail: mariusz_dybal@prawo.uni.wroc.pl. 
- The source of reimbursement of social security contributions from the Social Security Institution to pension funds are the proceeds from privatisation;

- The reform of the pension system is accompanied by measures taken to put an end to the privileges of sectoral and social groups in order to reduce public expenses.

The outcome of the research has proved the above hypotheses to be incorrect.

Key words: Social Insurance Institution (ZUS), Open Pension Funds (OFE), pension system

\section{Wstęp}

Wraz z początkiem 1999 roku wprowadzono w Polsce zmiany, które diametralnie odmieniły polski system emerytalny [Dybał, 2008, s. 35-52]. Stworzono system oparty na trzech filarach. Dotychczasowa emerytura z Zakładu Ubezpieczeń Społecznych (ZUS) została zastąpiona przez świadczenia z kilku źródeł. Pierwszym źródłem miał być zreformowany ZUS. Emerytura nadal była oparta na finansowaniu repartycyjnym, ale każdy ubezpieczony miał w ZUS konto, na które przelewano składkę emerytalna. W efekcie zastapienia zdefiniowanego świadczenia przez system zdefiniowanej składki, powiązano wysokość emerytury z wysokością przelewanych do ZUS składek. System miał być zbilansowany aktuarialnie. Drugi filar stanowiły prywatne Otwarte Fundusze Emerytalne (OFE), oparte na finansowaniu kapitałowym i systemie zdefiniowanej składki [Jakubowski, 2013, s. 36]. Uczestnictwo w ZUS i OFE było obowiazkowe22. Trzeci filar tworzyły prywatne emerytury finansowane kapitałowo, w których uczestnictwo było dobrowolne [Dybał, 2010, s. 229-246; Jakubowski, 2013, s. 3].

Było wiele przyczyn wprowadzenia reformy. Nie wchodząc w szczegóły, można powiedzieć, że miały charakter demograficzny, społeczny oraz może przede wszystkim ekonomiczny, gdyż zmierzano do odciążenia finansów publicznych - zbytnio obciążonych wydatkami emerytalnymi [Dybał, 2012, s. 75].

W wyniku wprowadzenia reformy, w nowym systemie emerytalnym zaczęły funkcjonować obok siebie dwa zjawiska. W pierwszym filarze było finansowanie repartycyjne, w drugim kapitałowe. W obu każdy ubezpieczony miał swoje konto, na którym ewidencjonowano składkę. W rezultacie, państwo musiało znaleźć pieniądze, aby wypłacić emeryturę w okresie przejściowym: dotychczasowym emerytom ze składek osób obecnie pracujących (czyli tak, jak do momentu wprowadzenia reformy) oraz dokonać płatności na rzecz członków OFE (nowe płatności powstałe przez wprowadzenie drugiego filara). Przewidywano, że dodatkowe wypłaty na konta w OFE spowodują deficyt w ZUS, ale najpóźniej w 2012 roku ZUS uzyska nadwyżkę [Shaping..., 1999, s. 46], a w długim okresie reforma emerytalna przyniesie osłabienie obciążenia systemem emerytalnym finansów publicznych ${ }^{3}$ [The 2012..., 2012, s. 328]. Według twórców reformy, deficyt w ZUS, powstały w wyniku przekazania składek do OFE, miał zostać sfinansowany wpływami z prywatyzacji oraz reformami mającymi ukrócić

${ }^{2}$ W zależności od wieku i charakteru pracy, dla pewnych osób uczestnictwo zarówno w ZUS, jak i OFE było dobrowolne lub zakazane.

3 Według Komisji Europejskiej, w perspektywie do 2060 roku wydatki na system emerytalny maja zmniejszyć się o 2,2\% PKB. 
przywileje grup społecznych, a tym samym zmniejszyć wydatki państwa [Shaping..., 1999, s. 40-50].

W związku z tym, ujawniła się przesłanka powstania artykułu - chęć weryfikacji przez autora następujących hipotez badawczych:

- Zakład Ubezpieczeń Społecznych uzyskał nadwyżkę między wpływami ze składek a wydatkami do pokrycia ze składek do roku 2012;

- $\quad$ źródłem refundacji kwot składek z ZUS do OFE są wpływy z prywatyzacji;

- $\quad$ reformie systemu emerytalnego towarzyszą działania zmierzające do ukrócenia przywilejów sektorowych oraz grup społecznych, służących zmniejszeniu wydatków państwa.

Powyższe hipotezy zostały poddane weryfikacji w wyniku realizacji celu badawczego pracy, którym była analiza wpływu postanowień decydentów na rachunki Zakładu Ubezpieczeń Społecznych. Dążąc do realizacji celu, autor:

- $\quad$ poddał analizie przepływy finansowe między ZUS, OFE a państwem;

- $\quad$ ustalił kwotę refundacji z tytułu przekazania składek do OFE;

- $\quad$ ustalił wpływy i rozdysponowanie przychodów z prywatyzacji;

- $\quad$ ustalił deficyt/nadwyżkę sektora instytucji rządowych i samorządowych;

- zdefiniował, a także ocenił wpływ postanowień decydentów na powyższe relacje.

Można zatem stwierdzić, iż podmiotem badań były: ZUS, OFE oraz państwo, a przedmiotem badań relacje między wymienionymi podmiotami, służące wypełnieniu założenia reformy emerytalnej - nadwyżki w ZUS do 2012 roku. Badaniu poddano głównie lata 1999-2012, a autor wykorzystał w pracy następujące metody badawcze:

- badania dokumentów;

- monograficzna;

- $\quad$ analizy i konstrukcji logicznej;

- $\quad$ analizy i krytyki piśmiennictwa;

- statystyczna.

\section{Rachunki Zakładu Ubezpieczeń Społecznych}

Zakład Ubezpieczeń Społecznych jest dysponentem Funduszu Ubezpieczeń Społecznych (FUS), który jest państwowym funduszem celowym, powołanym w celu realizacji zadań z zakresu ubezpieczeń społecznych [Ustawa..., 1998, s. 63] ${ }^{4}$. Tabela 1. przedstawia wpływy, wydatki oraz nadwyżkę/deficyt FUS. Na podstawie danych należy stwierdzić, iż w latach 1999-2012 zarówno wpływy, jak i wydatki FUS nieprzerwanie rok do roku były coraz wyższe. Na przykład wpływy w 1999 roku osiagnęły 73 707,8 mln PLN, podczas gdy w 2012 roku wyniosły $172000 \mathrm{mln}$ PLN. Z kolei, wydatki zwiększyły się w badanym okresie z 80 375,7 mln PLN do $176400 \mathrm{mln}$ PLN. W ciagu czternastu lat jedynie czterokrotnie osiagnięto nadwyżkę, a suma nadwyżek była wielokrotnie niższa od sumy deficytu za lata 1999-2012.

${ }^{4}$ Zob. art. 51, Dz.U. 1998, Nr 137 poz. 887 z późniejszymi zmianami. 
TABELA 1.

Wpływy i wydatki Funduszu Ubezpieczeń Społecznych (w mln PLN)

\begin{tabular}{|c|r|r|r|}
\hline Lata & Wpływy FUS & Wydatki FUS & Deficyt/Nadwyżka \\
\hline 1999 & 73707,8 & 80375,7 & $-6667,9$ \\
2000 & 80967,5 & 85684,0 & $-4716,5$ \\
2001 & 91563,7 & 96150,5 & $-4586,8$ \\
2002 & 95427,7 & 98834,2 & $-3406,5$ \\
2003 & 98618,7 & 102207,4 & $-3588,7$ \\
2004 & 107713,3 & 107567,7 & 145,6 \\
2005 & 110980,8 & 111075,5 & $-94,7$ \\
2006 & 120858,5 & 119233,0 & 1625,5 \\
2007 & 129628,1 & 121374,8 & 8253,3 \\
2008 & 136096,5 & 135649,8 & 446,7 \\
2009 & 138350,1 & 151486,5 & $-13136,4$ \\
2010 & 150108,1 & 160842,3 & $-10734,2$ \\
2011 & 155796,9 & 166667,3 & $-10870,4$ \\
2012 & 172000,0 & 176400,0 & $-4400,0$ \\
\hline
\end{tabular}

Źródło: opracowanie własne na podstawie: [Rocznik..., 2004, s. 13; Ważniejsze..., 2006, s. 7-9;

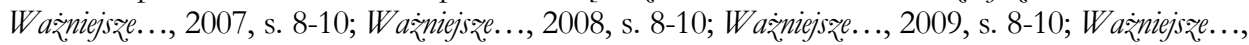
2010; s. 8-10; Ważniejsz̨e..., 2011, s. 8-10; Ważiejsz̨ ..., 2012, s. 8-10; dokument elektroniczny, tryb dostępu: http:/ /www.zus.pl/default.asp?p=2\&id=2358, data wejścia: 27.06.2013].

Tabela 1. stanowi punkt wyjścia weryfikacji/falsyfikacji hipotezy, że Zakład Ubezpieczeń Społecznych uzyskał nadwyżkę między wpływami ze składek a wydatkami do roku 2012. Warto zatem przedstawić strukturę wpływów i wydatków FUS. Według artykułu 52. Ustawy z dnia 13 października 1998 r. o systemie ubezpieczeń spolecznych5, przychody FUS pochodzą z kilkunastu źródeł, które w celu klaryfikacji wywodu można przyporządkować do dwóch grup:

- $\quad$ wpływy ze składek i należności pochodnych FUS;

- pozaskładkowe wpływy FUS.

Tak uporządkowaną strukturę wpływów FUS przedstawia tabela 2.

$\mathrm{Na}$ podstawie danych zawartych w tabeli 2. należy stwierdzić, iż wpływy ze składek i należności pochodnych FUS odznaczały się trendem rosnącym. W latach 1999-2012 wpływy z tego tytułu wzrosły z 64 248,8 do 121400 mln PLN. Przy czym, zauważalny był coroczny wzrost za wyjątkiem lat 2002 i 2008. Podobnie prezentują się pozaskładkowe wpływy FUS. Można również dostrzec trend rosnący, ale jedynie w latach 1999-2010, gdzie wpływy wzrosły z 9459 do 60 729,4 mln PLN. Tutaj także wystapiły odstępstwa od wzrostu w latach 2005 i 2009. Jedenak bardziej interesujące są dane za lata 2011-2012, które sugeruja przełamanie trendu wzrostowego, w wyniku obniżenia się pozaskładkowych wpływów do odpowiednio: 53 247,9 i $50600 \mathrm{mln}$ PLN. W efekcie, został przełamany trend spadkowy udziału wpływów ze składek i należności pochodnych na FUS we wpływach FUS. W latach 1999-2010, wspomniany,

${ }^{5}$ Zob. Dz. U. 1998, Nr 137, poz. 887 z późniejszymi zmianami. 
udział zmniejszył się z 87,2\% do 59,5\%, by w latach 2011-2012 zwiększyć się do odpowiednio: $65,8 \%$ i $70,6 \%$.

TABELA 2.

Struktura wpływów Funduszu Ubezpieczeń Społecznych (w mln PLN)

\begin{tabular}{|c|c|c|c|}
\hline \multirow{2}{*}{ Lata } & \multicolumn{2}{|c|}{ Wpływy FUS } & $\begin{array}{c}\text { Udział wpływów ze składek } \\
\text { i należności pochodnych na } \\
\text { FUS we wpływach FUS }\end{array}$ \\
\cline { 2 - 3 } & $\begin{array}{c}\text { Wpływy ze składek i należności } \\
\text { pochodnych FUS }\end{array}$ & $\begin{array}{c}\text { Pozaskładkowe } \\
\text { wpływy FUS }\end{array}$ & $87,2 \%$ \\
\hline 1999 & 64248,8 & 9459,0 & $81,0 \%$ \\
2000 & 65601,5 & 15366,0 & $76,9 \%$ \\
2001 & 70406,7 & 21157,0 & $71,7 \%$ \\
2002 & 68439,8 & 26987,9 & $71,3 \%$ \\
2003 & 70271,8 & 28346,9 & $68,7 \%$ \\
2004 & 74032,7 & 33680,6 & $70,4 \%$ \\
2005 & 78181,9 & 32798,9 & $67,3 \%$ \\
2006 & 81328,5 & 39530,0 & $68,9 \%$ \\
2007 & 89362,6 & 40265,5 & $60,8 \%$ \\
2008 & 82692,2 & 53404,3 & $62,5 \%$ \\
2009 & 86537,7 & 51812,4 & $59,5 \%$ \\
2010 & 89378,7 & 60729,4 & $65,8 \%$ \\
2011 & 102549,0 & 53247,9 & $70,6 \%$ \\
2012 & 121400,0 & 50600,0 & \\
\hline
\end{tabular}

Źródło: opracowanie własne na podstawie: [Rocznik..., 2004, s. 13; Ważniejsze..., 2006, s. 7-9;

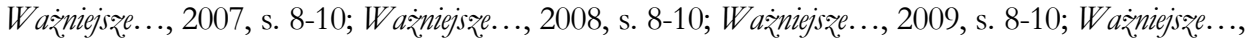
2010, s. 8-10; Waizniejsze..., 2011, s. 8-10; Ważniejsze ..., 2012, s. 8-10; dokument elektroniczny, tryb dostępu: http://www.zus.pl/defaultasp?p=2\&id=2358, data wejścia: 27.06.2013].

Z powyższej tabeli wynika, że pozaskładkowe wpływy charakteryzowały się większą zmiennościa, zatem zasadne jest przedstawienie ich struktury. Zgodnie $\mathrm{z}$ danymi w tabeli 3., w latach 1999-2012 pozaskładkowe wpływy FUS zanotowały trend wzrostowy z 7 196,3 do 42 581,5 mln PLN. Przeważnie ich wartość co roku była wyższa, za wyjątkiem lat: 2005, 2007, 2009, 2011. Na oszacowaną wysokość pozaskładkowych wpływów oddziaływały m.in. środki z budżetu państwa przeznaczone na:

- pokrycie wydatków na świadczenia pieniężne inne niż z ubezpieczenia społecznego, zlecone Zakładowi do wypłaty na mocy odrębnych przepisów, tj.: wypłaty świadczeń dla inwalidów wojennych i wojskowych oraz kombatantów, wypłaty pozostałych świadczeń niemających charakteru ubezpieczeniowego, m.in.: ryczałtów energetycznych, dodatków kombatanckich, dodatków dla żołnierzy-górników, świadczeń pieniężnych dla osób deportowanych do pracy przymusowej i osadzonych w obozach pracy przez III Rzeszę i ZSRR, jak również uzupełnienie części składek na ubezpieczenia społeczne za zatrudnione osoby niepełnosprawne; 
- $\quad$ uzupełnienie niedoboru składek z tytułu przekroczenia trzydziestokrotności podstawy wymiaru osób płacących składki, a także z tytułu niedoboru środków na wypłaty świadczeń;

- $\quad$ pokrycie wydatków na świadczenia pieniężne przyznawane w szczególnym trybie przez prezesa Rady Ministrów i prezesa ZUS.

TABELA 3.

Struktura pozaskładkowych wpływów FUS (w mln PLN)

\begin{tabular}{|l|c|c|c|c|}
\hline \multirow{2}{*}{ Lata } & \multicolumn{2}{|c|}{ Pozaskładkowe wpływy FUS } & \multicolumn{2}{c|}{$\begin{array}{c}\text { Udział refundacji z tytułu przekazania } \\
\text { składek do OFE }\end{array}$} \\
\cline { 2 - 5 } & $\begin{array}{c}\text { Refundacja z tytułu } \\
\text { przekazania składek } \\
\text { do OFE }\end{array}$ & $\begin{array}{c}\text { Pozostałe } \\
\text { pozaskładkowe } \\
\text { wpływy FUS }\end{array}$ & $\begin{array}{c}\text { Wpływy FUS } \\
\text { (w \%) }\end{array}$ & $\begin{array}{c}\text { Pozaskładkowe } \\
\text { wpływy FUS } \\
\text { (w \%) }\end{array}$ \\
\hline 1999 & 2262,7 & 7196,3 & $3,1 \%$ & $23,9 \%$ \\
2000 & 7548,2 & 7817,8 & $9,3 \%$ & $49,1 \%$ \\
2001 & 8652,9 & 12504,1 & $9,5 \%$ & $40,9 \%$ \\
2002 & 9490,4 & 17497,5 & $9,9 \%$ & $35,2 \%$ \\
2003 & 9868,0 & 18478,9 & $10,0 \%$ & $34,8 \%$ \\
2004 & 10613,0 & 23067,6 & $9,9 \%$ & $31,5 \%$ \\
2005 & 12575,4 & 20223,5 & $11,3 \%$ & $38,3 \%$ \\
2006 & 14920,4 & 24609,6 & $12,3 \%$ & $37,7 \%$ \\
2007 & 16219,3 & 24046,2 & $12,5 \%$ & $40,3 \%$ \\
2008 & 19911,5 & 33492,8 & $14,6 \%$ & $37,3 \%$ \\
2009 & 21086,0 & 30726,4 & $15,2 \%$ & $40,7 \%$ \\
2010 & 22347,2 & 38382,2 & $14,9 \%$ & $36,8 \%$ \\
2011 & 15430,8 & 37817,1 & $9,9 \%$ & $29,0 \%$ \\
2012 & 8018,5 & 42581,5 & $4,7 \%$ & $15,8 \%$ \\
\hline
\end{tabular}

Źródło: opracowanie własne na podstawie: [Rocznik..., 2004, s. 13; Ważniejsz̨e..., 2006, s. 7-9;

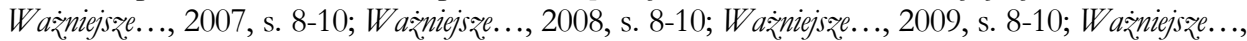
2010, s. 8-10; Ważniejsze..., 2011, s. 8-10; Ważniejsze..., 2012, s. 8-10; dokument elektroniczny, tryb dostępu: http:/ /www.zus.pl/default.asp?p=2\&id=2358, data wejścia: 27.06.2013].

Drugi element pozaskładkowych wpływów FUS stanowią środki z budżetu państwa, które są dla ZUS refundacją z tytułu przekazania składek do OFE. Na podstawie danych zgromadzonych w tabeli 3. należy stwierdzić, iż wartość refundacji w latach 1999-2010 nieprzerwanie rosła z poziomu 2 262,7 do 22 347,2 mln PLN. Dopiero w latach 2011-2012 refundacja uległa zmniejszeniu do odpowiednio: 15 430,8 i 8 018,5 mln PLN. Przyczyną zaistniałego zjawiska była decyzja rządzących o obniżeniu, dotychczas przekazywanej do OFE, składki emerytalnej z 7,3\% podstawy jej wymiaru do 2,3\% za okres od 1 maja 2011 do 31 grudnia 2012 roku. Powstała różnica w wysokości $5 \%$ podstawy wymiaru miała zostać zaewidencjonowana na subkoncie ubezpieczonego w ZUS [Dz. U. z 2011 r., Nr 75, poz. 398, art. 21-22]. W konsekwencji, został zahamowany wzrost udziału refundacji we wpływach FUS z 3,1\% i 14,9\% w latach 1999-2010 do odpowiednio: 9,9\% i 4,7\% w latach 2011-2012. W ostat- 
nich latach zmniejszył się również udział refundacji w pozaskładkowych wpływach FUS - z 36,8\% w 2010 roku do 29\% i 15,8\% w latach 2011-2012.

Ponieważ znana jest już wartość wpływów, wydatków oraz struktura rachunków ZUS, możliwa jest weryfikacja pierwszej hipotezy badawczej, której posłużyły dane zgromadzone w tabeli 4.

TABELA 4.

Wydatki FUS do pokrycia ze składek a wpływy ze składek

\begin{tabular}{|c|c|c|c|c|}
\hline \multirow[t]{2}{*}{ Lata } & \multicolumn{2}{|c|}{$\begin{array}{l}\text { Wydatki z FUS do pokrycia ze } \\
\text { składek }\end{array}$} & \multirow{2}{*}{$\begin{array}{l}\text { Wpływy ze } \\
\text { składek } \\
\text { i należności } \\
\text { pochodnych } \\
\text { w mld zł }\end{array}$} & \multirow{2}{*}{$\begin{array}{c}\text { Wskaźnik } \\
\text { pokrycia wydatków } \\
\text { wpływami ze } \\
\text { składek }\end{array}$} \\
\hline & w mld zX & w \% wydatków FUS & & \\
\hline 1999 & 77,1 & 96,0 & 64,2 & 83,3 \\
\hline 2000 & 82,4 & 96,2 & 65,6 & 79,6 \\
\hline 2001 & 92,5 & 96,2 & 70,4 & 76,1 \\
\hline 2002 & 95,4 & 96,5 & 68,4 & 71,7 \\
\hline 2003 & 98,6 & 96,5 & 70,3 & 71,3 \\
\hline 2004 & 104,1 & 96,8 & 74,0 & 71,2 \\
\hline 2005 & 107,5 & 96,7 & 78,2 & 72,8 \\
\hline 2006 & 115,7 & 97,1 & 81,3 & 70,3 \\
\hline 2007 & 121,1 & 99,8 & 89,4 & 73,8 \\
\hline 2008 & 135,4 & 99,8 & 82,7 & 61,1 \\
\hline 2009 & 151,2 & 99,8 & 86,5 & 57,2 \\
\hline 2010 & 160,6 & 99,8 & 89,4 & 55,7 \\
\hline 2011 & 166,4 & 99,9 & 102,5 & 61,6 \\
\hline 2012 & 176,2 & 99,9 & 121,4 & 68,9 \\
\hline
\end{tabular}

Źródło: opracowanie własne na podstawie: [Rocznik..., 2004, s. 13; Waìniejsze..., 2006, s. 14;

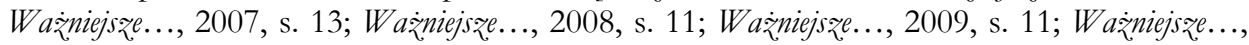
2010, s. 11; Ważniejsze..., 2011, s. 11; Ważniejsze..., 2012, s. 11; dokument elektroniczny, tryb dostępu: http:/ /www.zus.pl/default.asp?p=2\&id=2358, data wejścia: 27.06.2013].

Z tabeli 4. wynika, iż zdecydowany udział w wydatkach FUS miały wydatki do pokrycia ze składek (między 96\% a 99,9\%). Były to: wydatki na emerytury i renty, zasiłki z ubezpieczeń społecznych, jednorazowe odszkodowania powypadkowe, pozostałe świadczenia. Wydatki do pokrycia spoza składek objęły 0,1-4\% wydatków FUS i były to wydatki na działalność prewencyjna i pozostałe wydatki FUS. W latach 1999-2012 wydatki do pokrycia ze składek nieprzerwanie rosły, zwiększając swoją wartość z 77,1 mld PLN w 1999 roku do 176,2 mld PLN w 2012 roku. W badanych latach również wzrosły wpływy ze składek i należności pochodnych z 64,2 mld PLN w 1999 roku do 121,4 mld PLN w 2012 roku. Jednakże relacja między wpływami i wydatkami były niekorzystna. W latach 1999-2012 wskaźnik pokrycia wydatków wpływami zanotował trend spadkowy w latach 1999-2010, zmniejszając się z 83,3 do 55,7\%, by w latach 2010-2012 zanotować wzrost z 55,7 do 68,9\%. Tym samym zweryfikowano negatywnie hipotezę badawczą mówiąca, iż Zakład Ubezpieczeń Społecznych uzyskał nadwyżkę między wpływami ze składek a wydatkami do pokrycia ze składek do roku 2012. 
Skoro wiadomo, że nie uzyskano nadwyżki, warto zastanowić się, dlaczego tak się stało. Kwestię tę poruszono w kolejnym punkcie artykułu.

\section{Postanowienia decydentów}

Naturalną przyczyną braku nadwyżki między wpływami ze składek a wydatkami do pokrycia ze składek wydaje się sytuacja na rynku pracy, do której odnoszą się dane zaprezentowane w tabeli 5.

TABELA 5.

Sytuacja na rynku pracy

\begin{tabular}{|c|c|c|c|}
\hline Lata & $\begin{array}{c}\text { Pracujący w gospodarce } \\
\text { narodowej (w tys. osób) }\end{array}$ & $\begin{array}{c}\text { Bezrobotni zarejestrowani } \\
\text { ogółem (w tys. osób) }\end{array}$ & $\begin{array}{c}\text { Stopa rejestrowanego } \\
\text { bezrobocia ogółem }\end{array}$ \\
\hline 1999 &. & $\cdot$ &. \\
2000 & 15488,8 & 2702,6 & $15,1 \%$ \\
2001 & 14995,6 & 3115,1 & $17,5 \%$ \\
2002 & 12803,3 & 3217,0 & $20,0 \%$ \\
2003 & 12640,7 & 3175,7 & $20,0 \%$ \\
2004 & 12720,2 & 2999,6 & $19,0 \%$ \\
2005 & 12890,7 & 2773,0 & $17,6 \%$ \\
2006 & 13220,0 & 2309,4 & $14,8 \%$ \\
2007 & 13771,1 & 1746,6 & $11,2 \%$ \\
2008 & 14037,2 & 1473,8 & $9,5 \%$ \\
2009 & 13782,3 & 1892,7 & $12,1 \%$ \\
2010 & 14106,9 & 1954,7 & $12,4 \%$ \\
2011 & 14232,6 & 1982,7 & $12,5 \%$ \\
2012 &. & 2136,8 & $13,4 \%$ \\
\hline
\end{tabular}

Źródło: opracowanie własne na podstawie: [dokument elektroniczny, tryb dostępu: http://www.stat.gov.pl/gus/wskazniki_makroekon_PLK_HTML.htm, data wejścia: 27.06.2013].

Jeśli pracujących będzie mniej, a bezrobotnych coraz więcej lub dynamiki wzrostu poszczególnych grup będą niekorzystne, to nie uda się zrealizować nadwyżki. Po prostu, będzie zbyt mało wpływów ze składek osób pracujących, aby pokryć wydatki do pokrycia ze składek. Rzeczywiście, w latach 2005, 2007 stopa bezrobocia zmniejszyła się do odpowiednio: 17,6\% i 11,2\%, co niewątpliwie pomogło zwiększyć wskaźnik pokrycia wydatków wpływami ze składek do 72,8\% i 73,8\% oraz osiągnać najwyższą nadwyżkę między wpływami a wydatkami FUS. Z drugiej strony, w latach 20002003 stopa bezrobocia wzrosła z 15,1\% do 20\%, a mimo to deficyt FUS w tych latach był corocznie niższy. Wydaje się, że rozwiązanie tego zagadnienia można uzyskać dzięki analizie demograficznej struktury ludności. Tabela 6. przedstawia dane na temat struktury ludności w Polsce w latach 1999-2012 w podziale na ludność w wieku: przedprodukcyjnym, produkcyjnym, poprodukcyjnym i współczynnik obciążenia demograficznego. 
Według danych zawartych w tabeli, wynika, iż w latach 1999-2012 procent ludności w wieku przedprodukcyjnym corocznie się zmniejszał. Stąd w roku 1999 było 24,9\% osób w wieku 0-17 lat, podczas gdy w 2012 roku było ich tylko 18,3\%. Odwrotny trend należy zauważyć w stosunku do osób w wieku poprodukcyjnym. Zgodnie $\mathrm{z}$ danymi zawartymi $\mathrm{w}$ tabeli 6 ., kobiet $\mathrm{w}$ wieku ponad 59 lat oraz mężczyzn w wieku ponad 64 lata było 14,5\% w roku 1999, natomiast w roku 2012 już 17,8\% ogółu społeczeństwa. Zatem, mamy do czynienia z negatywnymi tendencjami demograficznymi, które powinny ujawnić się przy obliczaniu współczynnika obciążenia demograficznego. Jednak sytuacja nie jest jednoznaczna, gdyż w latach 1999-2008 poziom współczynnika zmniejszył się z 65 osób do 55 osób. Z kolei, w latach 20092012 współczynnik obciążenia zwiększył się do 57 osób. Przyczyną zmiany kierunku trendu współczynnika obciażenia ekonomicznego była sytuacja w grupie ludności w wieku produkcyjnym. Najpierw w latach 1999-2008 udział tej grupy ludności rósł z 60,6\% do 64,\%, by następnie zmaleć do 63,9\% w 2012 roku.

\section{Struktura ludności}

TABELA 6.

\begin{tabular}{|c|c|c|c|c|}
\hline Lata & \multicolumn{2}{|c|}{ Ludność w wieku (w \%) } & $\begin{array}{c}\text { Współczynnik ob- } \\
\text { ciążenia ekonomi- } \\
\text { cznego (ludność }\end{array}$ \\
\cline { 2 - 4 } & $\begin{array}{c}\text { Przedprodukcyjnym } \\
\text { (0-17 lat) }\end{array}$ & $\begin{array}{c}\text { Produkcyjnym } \\
\text { (18-59/64 lata) }\end{array}$ & $\begin{array}{c}\text { Poprodukcyjnym } \\
\text { (60/65 lat i więcej) }\end{array}$ & $\begin{array}{c}\text { wieku nieproduk- } \\
\text { cyinym na 100 osób } \\
\text { w wieku produkcyj- } \\
\text { nym) }\end{array}$ \\
\hline 1999 & & & & 65 \\
2000 & 24,9 & 60,6 & 14,5 & 64 \\
2001 & 24,4 & 60,8 & 14,8 & 63 \\
2002 & 23,5 & 61,5 & 15,0 & 60 \\
2003 & 22,7 & 62,2 & 15,1 & 59 \\
2004 & 21,9 & 62,9 & 15,2 & 57 \\
2005 & 21,2 & 63,5 & 15,3 & 56 \\
2006 & 20,6 & 64,0 & 15,4 & 56 \\
2007 & 20,1 & 64,2 & 15,7 & 55 \\
2008 & 19,6 & 64,4 & 16,0 & 55 \\
2009 & 19,3 & 64,5 & 16,2 & 55 \\
2010 & 19,0 & 64,5 & 16,5 & 55 \\
2011 & 18,8 & 64,4 & 16,8 & 56 \\
2012 & 18,5 & 64,2 & 17,3 & 57 \\
\hline
\end{tabular}

Źródło: opracowanie własne na podstawie: [dokument elektroniczny, tryb dostępu: http://www.stat.gov.pl/cps/rde/xbcr/gus/roczne_wskazniki_makroekonomiczne_cz_III_.xls, data wejścia: 21.01.2014; dokument elektroniczny, tryb dostępu: http://www.zus.pl/ files/dzial1.pdf, data wejścia: 21.01.2014].

$\mathrm{Z}$ drugiej strony, w latach 2011-2012 bezrobocie wzrosło do odpowiednio: 12,5\% i 13,4\%, zwiększył się również współczynnik obciążenia ekonomicznego, a mimo 
to wskaźnik pokrycia wydatków FUS wpływami ze składek zwiększył się do 61,6 i $68,9 \%$.

Zatem, muszą istnieć także inne czynniki wpływu. Za takie można uznać liczne modyfikacje i korekty systemu emerytalnego, które nie zawsze służyły poprawie jego finansowego zbilansowania. Tym samym w latach 1999-2012 decydenci podjęli następujące decyzje:

- $\quad$ wyłączenie w 2003 roku emerytur mundurowych z powszechnego systemu;

- przedłużenie w 2005 roku możliwości nabywania prawa do wcześniejszej emerytury do końca 2007 roku, a w 2007 roku przedłużenie do końca 2008 roku;

- $\quad$ wprowadzenie w 2005 roku emerytur górniczych;

- $\quad$ redukcja w 2007 roku składki rentowej [Præeglad..., 2013, s. 14].

W efekcie, zmniejszono dochody lub zwiększono wydatki FUS, stąd:

- całkowity koszt wcześniejszych emerytur górniczych w latach 2005-2020 wyniesie około 70 mld PLN, a w 2008 roku wcześniejsze emerytury górników kosztowały około 6,5 mld PLN;

- $\quad$ skumulowane koszty wpuszczenia do systemu 100 tys. nowych wczesnych emerytów to około 8,5 mld PLN (1,5 mld PLN rocznie), a w 2009 roku wszystkie emerytury wypłacane przez ZUS dla osób w wieku produkcyjnym kosztowały podatników ponad 23 mld PLN, w tym około 1,6 mld PLN ZUS wydał na wypłatę emerytur dla osób w wieku produkcyjnym, które po raz pierwszy zaczęły pobierać to świadczenie;

- $\quad$ koszt redukcji składki rentowej to kwoty od 0,1 mld PLN w 2011 roku do około 2,5 mld PLN w roku 2020 [Wojciechowski, Rzońca, 2010, s. 20].

Powyższe postanowienia pozwoliły zweryfikować negatywnie hipotezę o dążeniu do ukrócenia przywilejów sektorowych i branżowych. Ponadto, miały negatywny wpływ na wydatki państwa, gdyż spowodowały w latach 1999-2010 stopniowe obniżanie się wskaźnika pokrycia wydatków wpływami ze składek. Dopiero decyzje z lat 2011-2012 - o redukcji składki do OFE oraz utworzeniu subkonta w ZUS, podniesieniu wieku emerytalnego, podniesieniu składki rentowej, reformie emerytur mundurowych - spowodowały wzrost wskaźnika (tabela 4.).

Na wstępie pracy zauważono, że z założenia refundacja składek do OFE miała zostać sfinansowana wpływami z prywatyzacji. Dane na ten temat przedstawia tabela 7.

Gdyby w latach 1999-2012 wszystkie wpływy z prywatyzacji (124 $432 \mathrm{mln}$ PLN) zostały przekazane na refundacje z tytułu przekazania składek do OFE (178 944,3 mln PLN), to, wspomniana, refundacja zostałaby sfinansowana w $70 \%$. Przyczyną były zbyt niskie w stosunku do refundacji wpływy z prywatyzacji oraz poszerzenie katalogu celów, na które zaczęto przeznaczać wpływy z prywatyzacji. Oprócz reformy emerytalnej, środki z prywatyzacji zaczęto przeznaczać na:

- $\quad$ odpisy na cztery fundusze celowe: Fundusz Reprywatyzacji, Fundusz Restrukturyzacji Przedsiębiorstw, Fundusz Skarbu Państwa, Fundusz Nauki i Technologii Polskiej;

- $\quad$ wyodrębniony rachunek ministra właściwego do spraw pracy; 
- $\quad$ odpis na Rezerwy Poręczeniowe i Gwarancyjne Skarbu Państwa;

- odpis na Fundusz Rezerwy Demograficznej;

- $\quad$ restrukturyzację przemysłowego potencjału obronnego i modernizację techniczną Sił Zbrojnych RP [Marchewka-Bartkowiak, 2011, s. 3].

W konsekwencji, po odliczeniu ustawowych odpisów, osiagnięto wpływy netto z prywatyzacji, które w latach 1999-2012 wyniosły 83 876,2 mln PLN. Zatem, mogły sfinansować refundację składek do OFE jedynie w 47\%. Tym samym zweryfikowano negatywnie hipoteze jakoby źródłem refundacji składek do OFE byłyby wpływy z prywatyzacji.

Wpływy z prywatyzacji (w mln PLN)

TABELA 7.

\begin{tabular}{|c|r|r|r|}
\hline Lata & $\begin{array}{c}\text { Przychody } \\
\text { z prywatyzacji }\end{array}$ & $\begin{array}{c}\text { Wpływy netto } \\
\text { z prywatyzacji }\end{array}$ & $\begin{array}{c}\text { Refundacja z tytułu } \\
\text { przekazania składek } \\
\text { do OFE }\end{array}$ \\
\hline 1999 & 13383 & 13347,5 & 2262,7 \\
2000 & 27323 & 26746,2 & 7548,2 \\
2001 & 6835 & 6490,1 & 8652,9 \\
2002 & 2862 & 1971,6 & 9490,4 \\
2003 & 4143 & 2962,9 & 9868,0 \\
2004 & 10254 & 7370,5 & 10613,0 \\
2005 & 3848 & 2772,3 & 12575,4 \\
2006 & 621 & 446,2 & 14920,4 \\
2007 & 1947 & 1394,1 & 16219,3 \\
2008 & 2371 & 1021,3 & 19911,5 \\
2009 & 6592 & 568,9 & 21086,0 \\
2010 & 22037 & 9026,2 & 22347,2 \\
2011 & 13058 & 6267,6 & 15430,8 \\
2012 & 9158 & 3490,8 & 8018,5 \\
\hline Suma & 124432 & 83876,2 & 178944,3 \\
\hline
\end{tabular}

Źródło: opracowanie własne na podstawie: [Odpowiedź..., 2013; Prywatyzacja..., 2010; dokument elektroniczny, tryb dostępu: http://prywatyzacja.msp.gov.pl/portal/pr/349/24611/?poz=1, data wejścia: 30.06.2013; dokument elektroniczny, tryb dostępu: http://prywatyzacja.msp.gov.pl/ portal/pr/60/1529/Zestawienie_przychodow_z_prywatyzacji_stan_na_31122005_r.html, data wejścia: 30.06 .2013$]$.

$\mathrm{Na}$ podstawie powyższych danych należy stwierdzić, iż przyczyna falsyfikacji hipotez badawczych tkwi w postanowieniach decydentów, którzy byli odpowiedzialni za: zbyt niskie wpływy z prywatyzacji, poszerzenie katalogu celów finansowanych z prywatyzacji, niedotrzymanie założeń, a także wprowadzanie zmian do systemu emerytalnego, które skutkowały pogorszeniem stabilności finansowej FUS. Ponadto, mimo zakładanego w dniu startu reformy emerytalnej dążenia do ograniczania wydatków oraz uzdrawiania finansów państwa, na przestrzeni lat 1999-2012 co roku notowano deficyt sektora instytucji rządowych i samorządowych. 


\section{Podsumowanie}

Celem badawczym pracy była analiza wpływu postanowień decydentów na rachunki Zakładu Ubezpieczeń Społecznych. By go zrealizować, autor:

- $\quad$ poddał analizie przepływy finansowe między ZUS, OFE i państwem;

- $\quad$ ustalił kwotę refundacji z tytułu przekazania składek do OFE;

- określił wpływy oraz rozdysponowanie przychodów z prywatyzacji;

- $\quad$ sprecyzował deficyt/nadwyżkę sektora instytucji rządowych i samorządowych;

- zdefiniował, jak również ocenił wpływ postanowień decydentów na powyższe relacje.

W wyniku przeprowadzonych badań, zweryfikowano negatywnie zakładane hipotezy badawcze:

- ZUS nie uzyskał nadwyżki między wpływami ze składek a wydatkami do pokrycia ze składek do roku 2012 - coroczny deficyt, w tym w 2012 roku w wysokości 54,8 mld PLN, tj. 31,1\%;

- $\quad$ wpływy z prywatyzacji okazały się zbyt niskie - zrefundowały przekazanie składek do OFE jedynie w 47\%;

- $\quad$ reformie systemu emerytalnego przez długi okres nie towarzyszyły działania zmierzające do ukrócenia przywilejów sektorowych oraz grup społecznych, służących zmniejszeniu wydatków państwa, co więcej, przywileje powiększano - wyłączenie z powszechnego systemu emerytur mundurowych, przedłużenie możliwości nabywania prawa do wcześniejszej emerytury, wprowadzenie emerytur górniczych, redukcja składki rentowej.

\section{Literatura}

Dybał M. 2010 Istota i rodzaje systemón emerytalnych, [w:] Transformacje systemu gospodarčego, L. Olszewski (red.), „Ekonomia”, nr 18, Wydawnictwo Uniwersytetu Wrocławskiego, Wrocław .

Dybał M. 2008 Efektywnośc inwestycyjna fundussy emerytalnych, CeDeWu, Warszawa.

Dybał M. 2010 Funded Pension - a remedy for an ageing society?, „Wroclaw Review of Law, Administration and Economics", vol. 2, no. 2 .

Dokument elektroniczny, tryb dostępu: [http://prywatyzacja.msp.gov.pl/portal/ pr/349/24611/?poz=1, data wejścia: 27.06.2013].

Dokument elektroniczny, tryb dostępu: [http://prywatyzacja.msp.gov.pl/portal/ pr/60/1529/Zestawienie_przychodow_z_prywatyzacji_stan_na_31122005_r.h tml, data wejścia: 27.06.2013].

Dokument elektroniczny, tryb dostępu: [http://www.stat.gov.pl/gus/wskazniki_ makroekon_PLK_HTML.htm, data wejścia: 27.06.2013].

Dokument elektroniczny, tryb dostępu: [http://www.stat.gov.pl/cps/rde/xbcr/ gus/roczne_wskazniki_makroekonomiczne_cz_III_xls, data wejścia: 21.01.2014].

Dokument elektroniczny, tryb dostępu: [http://www.zus.pl/files/dzial1.pdf, data wejścia: 21.01.2014]. 
Dokument elektroniczny, tryb dostępu: [http://www.zus.pl/default.asp?p=2\&id= 2358, data wejścia: 27.06.2013].

Jakubowski S. 2013 Polish and global pension markets in the first decade of the second Millenium, „Social Research”, nr 1 (30).

Jakubowski S. 2013 Prawno-ekonomiczne aspekty gromadzenia i lokowania śodków przez Otwarty Fundusz. Emerytalny, PiEBC, Wrocław.

Marchewka-Bartkowiak K. 2011 Pryychody z.prywatyzacii i ich rozdysponowanie w budżecie państwa, Biuro Analiz Sejmowych, Warszawa.

Odpowied乏́. Ministra Finansón (sygnatura FN-6/0602/69-4/MAN/NJA/RWPD39173/2013/RD-50041/2013) na oświadczenie senatora Jana Wyrowińskiego ztożone podczas 32. posiedzenia Senatu RP w dnin 25 kwietnia 2013r. dotyczace konsekwencii wprowadzenia reformy systemu ubeapieczeń spotecznych dla stabilności finansów publicznych 2013, Warszawa.

Prywatyzacja 2010 na tle poprzednich lat 2010, MSP, Warszawa.

Przeglad funkecjonowania systemu emerytalnego wynikajacy z.art. 32 ustawy z dnia 25 marca 2011 r. o zmianie niektórych ustaw zwiqzanych \& funkecjonowaniem systemu ubezpieczeń spotecznych. Bezpieczeństwo driekei zrównoważeniu 2013, MPiPS oraz MF, Warszawa.

Rocznik. Statystyczny Ubezpieczeń Społecznych. System pozarolnicry 1999-2002 2004, ZUS, Warszawa.

Shaping Pension Reform in Poland: Security Through Diversity 1999, A. Chłoń, M. Góra, M. Rutkowski (red.), The World Bank.

The 2012 Ageing Report. Economic and budgetary projections for the 27 EU Member States (2010-2060) 2010, European Commision.

Ustawa ₹. dnia 25 marca 2011 r. o zmianie niektórych ustaw zwiqzanych ₹.funkcjonowaniem systemu ubezpieczeń spotecznych, Dz. U. z 2011 r., Nr 75, poz. 398, art. 21-22.

Ustawa z dnia 13 października 1998 r. o systemie ubezpieczeń społecznych, Dz. U. z 1998 r., $\mathrm{Nr} 137$, poz. 887 z poz. zm.

Wa:̇niejsze informacje z zakresu ubezpieczeń społecznych 2005r. 2006, ZUS, Warszawa. Ważniejsze informacje z zakeresu ubezpieczeń społecznych 2006r. 2007, ZUS, Warszawa. Wa:̇niejsze informacje z zakresu ubezpieczeń spolecznych 2007r. 2008, ZUS, Warszawa. Wa żniejsze informacje z zakeresu ubezpieczeń spotecznych 2008r. 2009, ZUS, Warszawa. Ważniejsze informacje z. zakeresu ubezpieczeń społecznych 2009r. 2010, ZUS, Warszawa. Ważniejsze informacje z. zakeresu ubezpieczeń społecznych 2010r. 2011, ZUS, Warszawa. Wojciechowski W., Rzońca A., 2010 Reforma emerytalna a finanse publiczne w Polsce, FOR, Warszawa. 